\title{
Review \\ Lessons from animal models of arthritis over the past decade
} Wim B van den Berg

\author{
Rheumatology Research and Advanced Therapeutics, Radboud University Nijmegen Medical Center, 6525 GA Nijmegen, The Netherlands
}

Corresponding author: Wim B van den Berg, w.vandenberg@reuma.umcn.nl

Published: 14 October 2009

This article is online at http://arthritis-research.com/content/11/5/250

(c) 2009 BioMed Central Ltd

Arthritis Research \& Therapy 2009, 11:250 (doi:10.1186/ar2803)

\begin{abstract}
This review summarizes the major developments in animal models of arthritis in the past decade. It focuses on novel transgenic models, addresses the involvement of cytokines and discusses novel findings in cartilage and bone erosion. It is clear that interest has been raised in the direct arthritogenic role of autoantibodies, apart from $\mathrm{T}$ cell involvement, and their interaction with cells through Fcgamma receptors. In addition, a role for IL-6 and IL-17 and Th17 cells seems apparent in most $\mathrm{T}$ cell-driven arthritis models, with environmental triggering through Toll-like receptors contributing to this process. Further insights into enzymes involved in cartilage proteoglycan loss in arthritis, as well as mediators regulating bone erosion and bone apposition, have been gained.
\end{abstract}

\section{Introduction}

Animal models have contributed to the understanding of basic mechanisms of joint disease. There is marked diversity among the numerous models, and arthritis has been induced by various stimuli. These include the generation of autoimmunity to cartilage components, nonspecific skewing of autoimmunity with adjuvants, and triggering with exogenous agents such as bacteria and viruses. More recently, focused transgenic manipulation has added novel variants (Table 1 ).

The wide variety of agents that can induce experimental arthritis with histopathological features close to those of human arthritides suggests that disparate etiological pathways may exist in rheumatoid arthritis (RA). No single animal model of arthritis truly represents the human disease, but the models mimic various aspects and can be used as tools to understand particular pathways.

Developments over the past decade include the generation of novel models as well as pathway analysis and therapeutic targeting in classic models. Aspects peculiar to individual models are of value but must be interpreted with caution. Much can be learned from the general validity of mediator involvement and other common concepts. This review will not discuss the developments in immune regulation and the use of models to identify disease susceptibility genes, but will focus on insights into cytokine involvement and aspects of joint destruction. The process of cartilage erosion remains hard to evaluate in patients. Synovial biopsies are now performed in many early arthritis clinics, but samples of damaged bone and cartilage become available only late in the disease, after joint replacement. Models therefore provide valuable tools.

Characteristic histopathological features of RA include immune complexes (ICs) in the articular cartilage layers and variable amounts of macrophages, T cells and plasma cells in the synovium, often accompanied by fibrosis and synovial hyperplasia. Formation of autoantibodies, including rheumatoid factor and the more recently discovered anti-citrulline or anti-citrullinated protein antibodies (ACPAs), is prominent, making $B$ cell activation and IC-mediated cellular inflammation likely contributors to pathogenesis. Indeed, perceptions have changed over the years and it is now generally accepted that IC arthritis models have their value and are increasingly used, although it must be emphasized that erosive arthritis is only achieved with high amounts of defined antibody cocktails. In fact, chronicity and joint erosions of IC arthritis are markedly amplified by the presence of a T cell component.

\section{Models of arthritis}

From a historical perspective, the models most widely used in the past decades have been adjuvant arthritis, collageninduced arthritis (CIA), antigen-induced arthritis (AIA) and streptococcal cell wall arthritis (Table 1). These models are classic examples of three driving elements: nonspecific immune deviation, targeted cartilage autoimmunity and abundant exogenous/infectious triggers. $T$ cells play a

$\mathrm{ACPA}=$ anti-citrullinated protein antibody; AIA = antigen-induced arthritis; CIA = collagen-induced arthritis; FcgR = Fcgamma receptor; GPI = glucose-6-phosphate isomerase; IC = immune complex; IFN = interferon; IL = interleukin; RA = rheumatoid arthritis; RANKL = receptor activator of NF-kappaB ligand; TGF $=$ transforming growth factor; TLR $=$ Toll-like receptor; TNF $=$ tumor necrosis factor. 
Table 1

\section{Models of arthritis}

\begin{tabular}{|c|c|c|c|c|c|c|}
\hline Model & Abbreviation & Species $^{a}$ & Feature & IC & $\mathrm{T}$ cell & References \\
\hline \multicolumn{7}{|l|}{ Trigger-induced models } \\
\hline \multicolumn{7}{|l|}{ Non-specific immune stimuli } \\
\hline Adjuvant-induced arthritis & AA & Lewis rat & Autoimmune & - & + & {$[1,2]$} \\
\hline Oil-induced arthritis & OIA & DA rat & Autoimmune & - & + & [3] \\
\hline Pristane-induced arthritis & PIA & DA rat & Autoimmune & - & + & {$[4,5]$} \\
\hline \multicolumn{7}{|l|}{ Cartilage directed autoimmunity } \\
\hline Collagen-induced arthritis & $\mathrm{ClA}$ & DBA mouse & $\mathrm{Cll} \mathrm{Al}$ & + & + & {$[6,7]$} \\
\hline Proteoglycan-induced arthritis & PGIA & Balb/c mouse & PG Al & + & + & {$[8,9]$} \\
\hline \multicolumn{7}{|l|}{ Infectious agents/exogenous triggers } \\
\hline Streptococcal cell wall arthritis & SCW-A & Lewis rat & Persistent bacteria Al & - & + & [10] \\
\hline Flare & SCW-F & Mouse & Th17 & - & + & [11] \\
\hline Antigen-induced arthritis & AIA & Rabbit, mouse & Persistent antigen & + & + & {$[12,13]$} \\
\hline Flare & AIA-F & Mouse & Th17 & - & + & [14] \\
\hline
\end{tabular}

Transgenic spontaneous models

HTLV-induced arthritis
KRN arthritis
SKG arthritis
GP130 arthritis
TNF transgenic arthritis
IL-1 ra transgenic arthritis
IL-1 transgenic arthritis

IL-1 transgenic arthritis

$\begin{array}{ll}\text { HTLV } & \text { Mouse } \\ \text { KRN } & \text { K/BxN mouse } \\ \text { SKG } & \text { Mouse } \\ \text { GP130 } & \text { Mouse } \\ \text { TNFtg } & \text { Mouse } \\ \text { IL-1ra-/- } & \text { Balb/c mouse } \\ \text { IL-1tg } & \text { Mouse }\end{array}$

Viral tax antigen
GPI AI
ZAP-70 T cell defect
STAT3, T cell defect
TNF overexpression
Autoimmune T cells
IL-1 overexpression

$\begin{array}{ccc}- & + & {[15]} \\ + & + & {[16,17]} \\ - & + & {[18,19]} \\ - & + & {[20,21]} \\ - & - & {[47,48]} \\ \pm & + & {[23]} \\ - & - & {[22]}\end{array}$

Immune complex models

\begin{tabular}{lllllc} 
Collagen type II & CAIA & DBA mouse & Mouse Cll antibody & + & - \\
KRN serum & GPI & Balb/c mouse & Mouse GPI antibody & + & - \\
Poly-L-lysine-lysozyme & PLL-L & DBA mouse & Cationic antigen & + & - \\
\hline
\end{tabular}

aMost commonly used. $\mathrm{Al}=$ autoimmune; $\mathrm{CAIA}=$ collagen antibody-induced arthritis; $\mathrm{GPI}=$ glucose-6-phosphate isomerase; $\mathrm{IC}=$ immune complexes as an early feature; $P G=$ proteoglycan.

dominant part in all of these models and this feature is a major principle of chronic erosive arthritis. Common models are summarized in Table 1 (see also [1-15] for further reading), but only novel developments are now discussed in more detail. Although T cell-directed therapy in RA was questionable for a while, insight into $T$ cell subclasses has grown and more subtle targeting of CTLA4 on T cell subsets looks promising. The recent discovery of Th17 as a distinct, pathogenic $T$ cell subset further boosted the interest in $T$ celldriven arthritis models.

\section{KRN arthritis}

An intriguing, novel arthritis model emerged from experiments in transgenic mice overexpressing a self-reactive $T$ cell receptor. $\mathrm{K} / \mathrm{BxN}$ mice, which express both the $\mathrm{T}$ cell receptor transgene KRN and the MHC class II molecule Ag7, develop arthritis [16]. In principle, many insults or adjuvants that skew regulation of $T$ cell tolerance have the potential to create autoimmune pathology, including joint inflammation. The major breakthrough and beauty of the KRN model is the elucidation of the driving antigen and the identification that 
passive transfer with antibodies induces protracted arthritis. In this model, the $\mathrm{T}$ cell receptor recognizes the ubiquitous self-antigen glucose-6-phosphate isomerase (GPI) and provokes, through B cell differentiation and proliferation, high levels of anti-GPI antibodies. These antibodies are directly pathogenic upon transfer and appear to recognize endogenous cationic GPI, which seems to associate preferentially with the cartilage surface [17]. The latter may underly the dominance of joint pathology in these mice, although GPI is also abundant at other sites in the body. This principle was already identified in AIA in mice, where antigen is planted in the knee joint of immunized mice. Cationicity of the antigen and sticking to cartilage greatly enhances arthritogenicity [13], demonstrating that either cartilage itself (for example, autoimmunity to collagen type II or proteoglycans) or antigens tightly associated with cartilage are major drivers of this. In KRN arthritis, IgG1 antibodies are the major subclass and cause a sustained, erosive arthritis after continued transfer, with high sensitivity in Balb/c mice. The pathology of this model is similar to that of passive CIA (CAIA) or IC arthritis, with planted cartilage-associated antigen, all including IC formation at the cartilage surface. Differences between the models relate to the $\lg \mathrm{G}$ subclasses involved.

\section{SKG and gp130 arthritis}

Another recent example of a transgenic $\mathrm{T}$ cell model is provided by the occurrence of chronic autoimmune arthritis in mice with a point mutation in the gene encoding ZAP-70, a key signal transduction molecule in T cells [18]. The aberrant $\mathrm{T}$ cell receptor function leads to positive selection of otherwise negatively selected autoimmmune $\mathrm{T}$ cells. Of high interest, these mice fail to develop disease under germ-free conditions despite active production of arthritogenic autoimmune cells. Apparently, the cells are in a resting state and need further activation before trafficking to joints and precipitation of arthritis occurs. A single injection of Zymosan provokes arthritis in a Dectin-1-dependent but Toll-like receptor (TLR)independent manner [19]. The latter is in sharp contrast with the arthritis in IL-1 ra-/- mice, which is similarly dependent on flora, but clearly TLR4 dependent. Th17 cells play a crucial role in SKG arthritis and identify that environmental factors such as yeast may drive or accelerate Th17 arthritis pathology.

Mice with a homozygous mutation in the gp130 IL-6 receptor subunit show enhanced signal transduction and STAT3 activation and develop lymphocyte-mediated RA-like joint disease, identifying another example of skewed $\mathrm{T}$ cell function resulting in arthritis. Increased proliferation of CD4+ T cells appeared due to elevated production of T cell-activating IL-7 by nonhematopoietic cells $[20,21]$.

\section{IL-1 transgenic mice and IL-1ra deficient mice}

Following the development of human TNF transgenic arthritis in the early 1990s, transgenic IL-1a overexpression was shown to induce chronic, destructive arthritis [22]. Transgenic mice expressing human IL-1a had high serum levels of
IL-1 and developed severe polyarthritis by 4 weeks of age. Hyperplasia of the synovial lining, pannus formation and, ultimately, cartilage destruction were evident. $T$ and $B$ cells were scant, but active granulocytes were abundant.

The opposite approach, elimination of IL-1 control by gene targeting of the endogenous $\mathrm{IL}-1$ receptor antagonist (IL-1 ra), yielded a $\mathrm{T}$ cell model of arthritis. IL-1 ra deficiency in a $\mathrm{Balb} / \mathrm{ca}$ background resulted in pronounced arthritis at the age of 8 weeks [23]. Marked synovial and periarticular inflammation was noted, with invasion of granulation tissue and articular erosion. Moreover, elevated levels of antibodies against immunoglobulins, type II collagen and double-stranded DNA were found, suggestive of autoimmune responses. Intriguingly, IL-1 ra deficiency in a C57Bl/6j background did not yield arthritis, but instead showed arteritis. This genetic variation, although not well understood, underscores an immunologic pathogenic pathway. Overexpression of a range of cytokines, including IL-1b, TNF and IL-6, was observed in the joints before onset of arthritis. Interestingly, autoantibody levels did not correlate with disease severity, which may imply that it reflects a reaction to damaged joint tissue.

In sharp contrast to the TNF transgenic model, the arthritis in IL-1 ra-/- mice is dependent on T cells, in line with the strong genetic restriction. It is consistent with the view that IL-1 is a crucial regulator of $\mathrm{T}$ cell function. Impaired $\mathrm{T}$ cell activation is demonstrated in IL-1 deficient mice, linked to low levels of CD40 ligand and OX40 expression on T cells, and underlies the suppression of collagen arthritis in $\mathrm{IL}-1-/-$ mice. Undisturbed IL-1 action, in the absence of IL-1ra, permits activation of IL-17-producing $T$ cells directed against exogenous triggers or endogenous autoantigens. The spontaneous arthritis in IL-1ra-/- mice does not develop under germ-free conditions and is reduced in TLR4-deficient mice. Both TNF and IL-17 deficiency prevent onset of arthritis [24,25].

\section{Immune complex arthritis}

Autoantibodies like rheumatoid factor and ACPAs are a key feature of RA and the recent success of treatment with an anti-B cell drug (Rituximab) supports the belief that they have a pathogenic role in it. In some of the models, such as collagen-, proteoglycan- and antigen-induced arthritis, immune complex formation at joint tissues is a major element of the disease. Excessive immune complex formation can cause destructive arthritis but chronicity is limited, although it is greatly enhanced by $T$ cells. The latter may be linked to the need for $T$ cells to sustain antibody production, and the greater potential of $\mathrm{T}$ cell macrophage interaction to sustain joint pathology. Minute amounts of antigen suffice to stimulate $\mathrm{T}$ cells, whereas considerable amounts of ICs are needed to stimulate inflammatory mediator release from phagocytes. It is likely that IC models mimic part of the RA pathology.

There is growing interest in the use of passive IC models, together with a range of transgenic knockouts, to identify 
crucial pathways of inflammation and tissue destruction. The advantage of passive systems is lower dependence on genetic background, avoiding excessive back-crossing to create transgenics in suitable, susceptible mouse strains.

\section{Passive collagen-induced arthritis}

Passive transfer of collagen arthritis can be performed with a critical mixture of a number of anti-collagen type II monocloclonal antibodies, including complement binding $\lg 22 a[26,27]$. Sets are now commercially available, routinely recommending DBA mice as sensitive recipients and additional lipopolysaccharide injection for synchronization of expression. Accepted concepts of inflammation pathways include IC-mediated complement activation and Fcgamma receptor (FcgR) triggering on phagocytes. Proteoglycan antibodies from the proteoglycan arthritis model can induce transient arthritis upon transfer, with concomitant proteoglycan loss from the cartilage, but no erosive damage. IgG1 seems to be the critical lgG subclass, but its destructive potential is not yet clear.

\section{Passive poly-L-lysine-lysozyme arthritis}

An IC model emerging from the murine AIA model and using the principle of cationic retention involves passive transfer of anti-lysozyme antibodies to mice that are locally injected in one knee joint with poly-L-lysine-coupled lysozyme. Poly-Llysine-coupled lysozyme is highly cationic and sufficiently large to be retained in the joint for prolonged periods of time. Both association with synovial tissue and heavy sticking to cartilage surfaces contributes to chronicity and cartilage destruction. An intriguing observation is the more chronic and destructive nature of this arthritis in $\mathrm{DBA} / 1 \mathrm{j}$ compared to Balb/c mice [28], which seems related to high sustained levels of activating FcgRs on macrophages of DBA/1j mice. The model shows strong dependence on IL-1, whereas TNF blockade was ineffective [29]. FcgRl rather than FcgRIII appears to be crucial for cartilage damage [30].

\section{Passive KRN/glucose-6-phosphate isomerase arthritis}

Antibodies present in the serum of arthritic KRN mice are directly pathogenic upon systemic transfer. They recognize endogenous GPI, which seems to associate preferentially with the cartilage surface $[17,31,32]$. The latter may underlie the dominance of joint pathology in these mice, although GPI is also abundant at other sites in the body and other pathologies are noted as well. This observation opened a wide search for the relevance of such antibodies in RA, but they are not present at high levels and are not found in all patients and their role in RA remains to be proven. IgG1 antibodies are the major lgG subclass in this model and cause a sustained, erosive arthritis after continued transfer, with high sensitivity in Balb/c mice [1]. Large variation is noted in the various mouse strains, making it crucial to use proper control mice with a defined genetic background when pathway studies are done in particular knockout mice, which are often available in mixed genetic backgrounds. Serum is more active than purified anti-GPI antibodies, suggesting the presence of arthritis-promoting cofactors such as TLR ligands or cytokines. Repeat injections enhance chronicity and joint destruction. The model comes close to passive CIA and IC arthritis, with planted cartilage-associated antigen, all having IC formation at the cartilage surface as a salient feature.

Recently, an adaptation of this arthritis model was developed by immunization with GPI in Freunds adjuvant. This model is a mix of IC and T cell-driven arthritis [33,34]. Serum from this model was not able to transfer arthritis, indicating that antibodies generated with this immunization are poorly arthritogenic. Upscaling or the use of a critical mixture of multiple epitope-recognizing antibodies is needed, similar to observations with anti-collagen type II antibodies.

\section{Passive citrulline-induced arthritis}

In line with the identification of ACPAs as an early marker of the RA process, many groups have attempted to induce citrulline arthritis. Consensus on whether such antibodies occur in classic arthritis models has not yet been reached due to inconsistencies in the detection of true ACPAs and omission of proper controls for antibodies cross-reactive with non-citrullinated components. In fact, many groups have failed to detect true ACPAs and much of the circumstantial evidence for them comes from unpublished observations. Yet, an initial study supporting the arthritogenic role of anticitrulline immunity in collagen arthritis was provided by Holers and colleagues [35]. Intriguingly, mice tolerized to citrulline showed reduced collagen arthritis, suggestive of a contribution of citrulline in CIA, although bystander suppression rather than specific tolerization can not be excluded. In a transgenic mouse bearing the human RA-associated shared epitope (Dr4), it was subsequently demonstrated that arthritis could be induced by immunization with citrullinated fibrinogen [36], but the arthritis was different from RA or classic CIA. Very recently, Holmdahl's group generated a range of antibodies specific for citrullinated collagen type II and showed induction of arthritis upon transfer [37]. In addition, the antibodies could amplify smoldering collagen arthritis. This amplifying principle was also found in the past for rheumatoid factor. The difficulty of showing arthritogenic potential and the need for mixtures of antibodies to facilitate arthritis expression may explain why antibodies can be already detected 5 years before the onset of RA. Epitope spreading [38] and the creation of a critical mix of antibodies, allowing the generation of large polyclonal IC networks, might be crucial.

\section{IgG, Fcgamma receptors and complement}

ICs interact with macrophages and granulocytes mainly through FcgRs. In this decade FcgRllb was identified as an inhibitory receptor, regulating the activity of the activating FcgRI and FcgRIII. Deletion of the Ilb receptor renders $\mathrm{H}-2 \mathrm{~b}$ mice susceptible to collagen arthritis [39]. Likewise, it was 
shown that DBA-1j and B10RIII mice, which are highly susceptible to CIA, have a skewed FcgR balance compared to non-susceptible C57BI and Balb/c mice [28]. DBA mice have high levels of the stimulatory type III receptor on resting macrophages whereas cells from B10RIII mice have normal levels but show skewing in favor of type III over type IIb receptors upon triggering with inflammatory stimuli. This argues that mice and individuals have different susceptibilities to IC arthritis dependent on their FcgR make up.

A complicating factor in extrapolating data from mouse to human is the fact that human cells have another dominant activating type receptor, FcgRlla. A transgenic mouse was generated bearing human FcgRlla. Intriguingly, this mouse develops spontaneous multisystem autoimmune disease, including arthritis with aging [40]. In addition, these mice develop CIA more rapidly and show a severe phenotype. Of interest, antagonists developed for this activating FcgRlla showed therapeutic efficacy in CIA in these mice [41].

A recent discovery in this field is the identification of a novel receptor, FcgRIV. Its contribution to joint pathology remains to be studied. For further reading, a review by Boross and Verbeek is recommended [42].

Apart from triggering of FcgRs, complement activation plays a major role in IC-mediated arthritis. Both the classic and alternative pathways of complement activation can contribute [43], the relative contributions of which are probably mainly dependent on the subclasses of antibodies present, adherence to joint surfaces as well as the genetic background of the mice [17]. More recently, a major amplifying role of the alternative pathway was identified in the passive CIA model performed in a series of mice genetically deficient in components of the complement pathways [44]. Intriguingly, a novel selective inhibitor of the alternative complement pathway markedly reversed inflammation and bone destruction [45].

\section{Role of cytokines}

Findings on the involvement of TNF, IL-1, IL- 6 and IL-17 in arthritis and concomitant joint destruction will be discussed below in more detail. In general, TNF is a major mediator in the early stages of joint inflammation in every experimental arthritis model. Although IL-1 is not a dominant early inflammatory cytokine in all models, it is the pivotal cytokine in inhibition of chondrocyte proteoglycan synthesis in the articular cartilage in all models studied so far and blocking of it has great beneficial impact on net cartilage destruction [46]. In line with this, chronic destructive arthritis could not be induced in IL-1 deficient mice using any of the classic arthritis models and this holds as well for the more novel models such as KRN and SKG arthritis and passive GPI/KRN arthritis. In fact, both $T$ cell- and IC-driven murine models appear IL-1 dependent. In contrast, TNF deficiency reduced the incidence of autoimmune arthritis expression in most models, but once joints became afflicted full progression to erosive arthritis did occur in the full absence of TNF. It is not yet clear why IL-1 is such a dominant target in IC- and T cell-driven murine arthritis models, whereas a crucial role for IL-1 in autoimmune RA in humans is still questionable or even unlikely. The latter statement is based on the successful targeting of IL-1 with IL-1ra in proven IL-1-dependent diseases such as Mediterranean fever or gout. The identification of the novel T cell cytokine IL-17, its role in arthritis models and the strong dependence on IL-1 for the generation of Th17 cells in mice, but certainly also in humans, provides an even greater enigma. This may argue that, in human RA, the contribution of IL-1 is overruled, or dominant pathways besides autoimmune IC- and T cell-driven processes play a role and have yet to be identified.

\section{TNF/IL-1 involvement}

In 1991, Kollias and coworkers provided insight into the possible role of TNF in arthritis induction in an elegant series of experiments. By introducing into mice a modified human TNF transgene lacking a TNF 3' untranslated region involved in translational repression of TNF, it was shown that pronounced TNF overexpression results in chronic polyarthritis with a $100 \%$ incidence [47]. Hyperplasia of the synovium, inflammatory infiltrates in the joint space, pannus formation, and cartilage and bone destruction were observed. Intriguingly, a similar form of arthritis also developed in targeted mutant mice lacking the 3' AU-rich elements, confirming the role of these elements in the maintenance of a physiological TNF response in the joint [48]. A proposed mechanism for this is the inability of natural anti-inflammatory signals such as IL-10 to suppress TNF production under these conditions. These exciting findings stimulated a major search for functional mutations around TNF production in RA patients. However, no clear indications have so far been found. Further investigation of TNF receptor involvement showed a crucial role of the p55 type I receptor in mediating TNF pathology, and a suppressive role of the p75 type II receptor. This implies a dualistic pro-inflammatory and immunosuppressive role for TNF and heterogeneity of TNF receptor usage in autoimmune suppression versus inflammatory tissue damage $[49,50]$. These observations may provide a rationale for future treatment of RA with selective anti-TNF receptor instead of antiTNF antibodies.

The TNFtg model gained much interest and is now used in many labs to identify downstream pathways of TNF-induced joint pathology and to screen the efficacy of various TNFdirected therapies. It is not surprising that anti-TNF treatment blocks the pathology, but it is a remarkable observation that $\mathrm{IL}-1$ is a major downstream mediator. Crosses between TNFtg and IL-1 deficient mice yielded insight into IL-1dependent elements and it was convincingly demonstrated that TNF drives inflammation. However, bone erosion is partly dependent on IL-1 and cartilage erosion is completely dependent on it [51]. It identifies that even in a fully TNFdriven system, IL-1 is solely responsible for cartilage erosion 
and this aspect needs further attention in clinical trials. Joint erosion scores are often dominated by bone erosion, whereas joint space narrowing, if included, is an insensitive measure of focal cartilage erosion and the impact of IL-1 blocking may be underestimated.

As already mentioned above, in many IC- or $\mathrm{T}$ cell-driven arthritis models TNF is important at onset of disease, but less involved at later stages, when IL-1 and IL-17 become major players. This is found in CIA [52,53], KRN arthritis [32], SKG arthritis [18] and spontaneous arthritis in IL-1ra-/- mice $[24,25,54]$. In an attempt to create a model with stronger macrophage involvement, yet using natural stimuli, we repeatedly injected streptococcal cell wall fragments into the murine knee joint, creating chronicity by repeated flares. Earlier we showed that such flares can be achieved with both homologous or heterologous fragments [55]. Every flare remained TNF dependent in terms of swelling, yet chronic infiltrate and concomitant joint erosion became IL-1 dependent, and the model also displayed a gradually increasing role of $\mathrm{T}$ cell-derived IL-17 and IL-17 receptor-bearing synoviocytes $[11,56]$. Recently, IL-32 was discovered as a novel human cytokine driving TNF expression. It induces arthritis in mice [57], but an endogenous murine analog of this cytokine has not been found yet, hampering mechanistic studies on its role as an upstream mediator.

\section{IL-6/IL-17 involvement}

IL-6 has been detected as an abundant cytokine in washouts of inflamed joints under many experimental model conditions. Although its function is pleiotropic, therapy was developed directed at the IL-6 receptor and humanized anti-IL-6 receptor antibodies now appear efficacious in human RA. It is already an old observation that AIA and Zymosan-induced arthritis are suppressed in IL-6 deficient mice [58]. Nowadays it is becoming more clear that the underlying mechanism of this suppression may be linked to the role of IL- 6 in the generation of pathogenic Th17 cells. Th17 cells were recently identified as a separate T cell lineage, apart from Th1 and Th2 cells, and numerous groups have demonstrated a crucial role for IL-6 and IL-1, potentially together with transforming growth factor (TGF) $\beta$, in their generation $[59,60]$. IL-23 appears to be a propagation factor of Th17 cells, rather than a crucial inducing factor. Recent studies show that blockade of IL-6 activity with anti-IL-6 receptor antibodies suppresses both GPI [34] and CIA [61], whereas evidence was obtained of reduced Th17 induction. Of interest, this effect was not noted with anti-TNF treatment, making IL-6 receptor-directed targeting a potential alternative therapy in patients refractory to TNF blockade.

Before the identification of Th17 cells in 2005 as a separate lineage, IL-17 was already seen as a novel cytokine displaying arthritogenic potential apart from IL-1 and TNF. Local overexpression using adenoviral IL-17 gene constructs showed that it can accelerate inflammation and tissue destruction in
CIA [62], and greatly amplifies passive KRN arthritis [63], concomitantly causing accelerated $\mathrm{CIA}$ and KRN arthritis independent of IL-1 and TNF, respectively. This illustrates that arthritis can become refractory to TNF and IL-1 blocking when IL-17/Th17 dominates the process. Exploration of the efficacy of anti-IL-17 antibodies in arthritis models revealed suppression of inflammation and tissue damage in CIA [64] and superior suppression in T cell-driven flares of AIA compared to the acute stages of AIA [14]. It also revealed suppression of spontaneous arthritis in IL-1 ra-/- mice [55], in line with the absence of this arthritis in $\mathrm{IL}-17$ deficient mice [24]. As an exception to the rule, autoimmune proteoglycaninduced arthritis appears mainly a Th1-mediated model, in contrast to most Th17-driven arthritis models. The reason for this peculiar phenotype is largely unexplained. It is suppressed but not completely prevented in IFN $\gamma$-deficient mice, whereas proteoglycan-induced arthritis could be easily elicited in IL-17-deficient mice, to demonstrate that severe and destructive arthritis can occur independently of IL-17 [65]. Interestingly, IFN $\gamma$-deficient mice did not show complete absence of disease, but merely a delayed onset, suggesting an early role for Th1 cells in this model. A role for IL-17 in late disease was unmasked in IFN/IL-17 double knockouts, showing complete suppression of both early and late arthritis (A Finnegan, personal communication).

\section{Impact of environment and co-stimuli}

Recently, TLRs were discovered as major receptors involved in pattern recognition of bacteria and viruses. Using another model of autoimmune inflammation, Luger et al. [66] showed that conditions of disease induction affect whether the Th17 or Th1 effector category is dominant. After immunization with retinal antigen IRBP in complete Freund's adjuvant, IL-17dependent uveitis develops, whereas induction of experimental autoimmune uveitis with IRBP-pulsed mature dendritic cells results in the generation of an IFN $\gamma$-producing effector response. The data indicate that the conditions of the initial antigen exposure, including the quality/quantity of TLR stimulation and/or type of antigen presenting cells, determine the dominant effector phenotype. Likewise, IL-1ra-/- mice develop spontaneous Th17-dependent arthritis under normal housing conditions, but arthritis is completely lost under germfree conditions. This suggests that bacterial flora drive the generation of autoimmune Th17 cells under conditions of excess IL-1. Crossing studies with various TLR deficient mice identified that TLR4, in particular, was responsible for skewing towards Th17 responses and development of an erosive arthritis phenotype [67]. Of therapeutic interest, TLR4 blocking, using a receptor antagonist, blocked both IL-1ra-/arthritis as well as CIA [68], identifying TLR4 as a novel target.

As an aside, passive KRN arthritis is IL-1 dependent and is greatly reduced in IL-1R deficient mice. Intriguingly, when the TLR4 agonist lipopolysaccharide is applied as an additional stimulus, IL-1 dependency is overruled and arthritis progresses undisturbed [69]. It illustrates that lipopolysaccharide 
stimulation can mimic IL-1 action and IL-1 dependency can be lost in the presence of such environmental co-stimuli.

We need to be aware that animal models are strongly restricted in terms of exposure to environmental triggers common to humans due to clean pathogen controlled housing conditions. As an example, a link between smoking and occurrence of ACPAs has been demonstrated in RA patients, a condition not encountered in experimental studies with mice.

\section{Crucial synovial cells}

The local architecture of the synovial tissue is of prime importance for arthritis expression. We showed earlier that depletion of synovial lining cells using chlodronate laden liposomes prevents expression of arthritis [70], in line with a major role for these cells in local cytokine and chemokine production. A major development was the identification of Cadherin 11 as a crucial factor in the organization of synovial architecture. Cadherin 11 deficient mice have a hypoplastic synovial lining, display a disorganized synovial reaction to inflammation and are resistant to inflammatory arthritis [71]. Cadherin-11 therapeutics prevent and reduce arthritis in mice. Apart from synovial lining cells, the presence of mast cells makes a joint vulnerable to arthritis expression. Mast cell deficient mice lose susceptibility to passive GPI arthritis, identifying mast cell activation and concomitant IL-1 release as a dominant feature in the precipitation of arthritis at distinct sites [72]. This is in keeping with the old observation that preferential expression of arthritis occurs at sites that contain abundant numbers of mast cells, such as footpads.

\section{Cartilage and bone destruction}

Animal models are excellent tools to characterize destructive pathways. Cartilage damage observed in models ranges from a reversible loss of proteoglycans to collagen damage, cell death and complete surface erosion. This underlines that arthritic processes can be more or less destructive, dependent on the underlying (immune) process and cytokine mixture [73]. Collagen breakdown and aggressive cartilage loss is predominantly noted in the presence of immune complex deposition, whereas milder, more gradual forms of damage are seen in models driven by macrophage or $\mathrm{T}$ cell activation. Large variation in progressive destruction is also observed in patients with RA, with the presence or absence of autoantibodies (rheumatoid factor, ACPAs) contributing to this.

It was long debated whether proteoglycan loss contributes to erosive damage. Elegant studies were performed in ADAMTS4 and ADAMTS5 knockout mice, which are deficient in the major enzymes involved in the degradation of aggrecan, the dominant proteolgycan of articular cartilage. One identified the crucial role of ADAMTS5 in early proteoglycan loss in AIA [74]. In addition, aggrecan knockin mice were generated with a mutation in the major aggrecanase cleavage site, making the aggrecan resistant to specific breakdown. Intriguingly, cartilage erosion was not only diminished in AIA in these mice, but cartilage repair was stimulated following inflammation [75]. This makes ADAMTS5 a promising target in RA, potentially preventing erosive collagen damage if treatment is started early enough. The cytokines TNF, IL-1 and IL-17 can drive aggrecanase production, but other mediator systems can as well, making enzyme targeting warranted. As an aside, experimental osteoarthritis is also markedly reduced in ADAMTS5 knockouts [76], identifying a promising therapeutic target in this disease with large unmet medical needs.

Apart from aggrecanases, studies in immune models in various FcgR knockout mice further identified that FcgRI is pivotal in driving IC-mediated cell activation, metalloproteinase activation and concomitant cartilage erosion [77-79]. This receptor or its downstream activation pathways provide challenging therapeutic targets. Of great interest, the absence of FcgRl blocked cartilage damage, yet had no impact on bone erosion. In fact, bone erosion is independent of FcgRs. Arthritis in FcgRI, II and III knockouts is pronounced and sustained due to defective clearance of ICs and cartilage erosion is absent although bone erosion is enhanced, in line with enhanced cytokine production under these conditions.

Cytokines like TNF, IL-1 and IL-17 cause bone erosion through up-regulation of receptor activator of NF-kappaB ligand (RANKL), formerly called osteoprotegerin ligand [80]. Like cartilage damage, bone erosion may occur uncoupled of inflammation. Local gene transfer with IL-4 did not suppress joint inflammation, yet markedly reduced cartilage and bone destruction in CIA through suppression of RANKL [81]. Likewise, in RANKL deficient mice, joint inflammation continues in passive KRN/GPI IC arthritis, but bone erosion is prevented [82]. Similarly, when TNF transgenic mice were crossed with c-fos deficient mice, joint inflammation continued, yet bone erosion was fully absent. c-fos mice lack functional osteoclasts and in this background TNFtg mice show a nondestructive phenotype. In line with this, treatment with osteoprotegerin, which is the natural inhibitor of RANKL, did not reduce inflammation in adjuvant arthritis and TNF transgenic mice, yet bone erosion was reduced [83].

The above examples identify that inflammation, bone erosion and cartilage erosion are separate processes, potentially needing selective therapy. Further improvement of therapy, including for bone repair, can be achieved with the combined blocking of cytokines and RANKL, together with an additional bone anabolic stimulus such as parathyroid hormone [84,85]. Models also demonstrate that bone repair is evident when inflammation wanes, but cartilage repair is more difficult to achieve and is often defective. Anabolic stimulation and tissue engineering approaches are needed when structural damage is too far advanced

A final remark regards bone erosion versus bone apposition. Unlike the situation in RA patients, many arthritis models show bone erosion but also pronounced new bone formation 
at the joint margins. Adjuvant arthritis in the rat is the most prominent example, characterized by major bone apposition early in the process, with limited to no cartilage erosion in the beginning and inflammation as well as bone erosion predominantly located in the bone marrow areas; however, KRN arthritis and CIA also show pronounced bone apposition. This apposition is less in arthritis in IL-1 ra-/- mice and virtually absent in TNFtg mice, both models showing a gradual but slow progression of arthritis. Of great interest, a TNF-inducible regulator of bone apposition, Dickkopf-1 (DKK1), was recently identified [86]. By inhibiting DKK-1, a regulatory molecule of the Wnt pathway, the bone destructive pattern was inhibited in TNFtg mice and reversed to a bone forming pattern, resembling osteoarthritis. This might indicate that most murine arthritis models are relatively devoid of TNF compared to human RA. Of interest, we have identified TGF $\beta$ as a major driver of osteophytes in experimental osteoarthritis [87]. TGF $\beta$ levels are high in both experimental osteoarthritis and RA models, suggesting that the balance between it and other regulators such as DKK-1 is important.

\section{Conclusion}

Models are tools that mimic aspects of human disease. It is clear that animal models have contributed considerably to further our understanding of arthritic processes and concomitant cartilage and bone destruction, and have provided novel insights and treatment targets. However, final proof of the use of data determined using these models lies in clinics; time will tell whether model data are predictable for certain targets and, as such, clinical data will help shape and define the models. TNF and IL- 6 are good examples of molecules with general pro-inflammatory roles that were identified in various models and against which targeted therapies with antibodies have shown consistent efficacy in human RA. RANKL also seems to fit into this category, with a consistent role in bone erosion in many conditions. IL-17 seems a promising target, and we await further identification of its role in subgroups of RA with a distinct T cell signature. Increasing support for a pathogenic role of autoantibodies in RA has shifted the interest of researchers to passive IC models such

\section{The Scientific Basis of Rheumatology: A Decade of Progress}

This article is part of a special collection of reviews, The Scientific Basis of Rheumatology: A Decade of Progress, published to mark Arthritis Research \& Therapy's 10th anniversary.

Other articles in this series can be found at: http://arthritis-research.com/sbr as KRN serum transfer or passive CIA (collagen II antibody transfer). Their use is biased by ease of induction. In addition, it remains a concern that these models are strongly IL-1 dependent whereas the role of $\mathrm{IL}-1$ in RA patients seems limited to destructive processes.

\section{Competing interests}

The author declares that they have no competing interests.

\section{References}

1. Pearson CM: Development of arthritis, periarthritis and periostitis in rats given adjuvants. Proc Soc Exp Biol (New York) 1956, 91:95-101

2. Van Eden W, van der Zee R, Prakken B: Heat shock proteins induce $\mathrm{T}$ cell regulation of chronic inflammation. Nat Rev Immunol Rev 2005, 5:318-330.

3. Kleinau S, Erlandsson H, Holmdahl R, Klareskog L: Adjuvant oils induce arthritis in the DA rat. I. Characterization of the disease and evidence for an immunological involvement. $J$ Autoimmunity 1991, 4:871-880.

4. Wooley PH, Seibold JR, Whalen JD, Chapdelaine JM: Pristane induced arthritis. The immunologic and genetic features of an experimental murine model of autoimmune disease. Arthritis Rheum 1989, 32:1022-1030.

5. Holmdahl R, Lorentzen JC, Lu S, Olofsson P, Wester L, Holmberg $\mathrm{J}$, Pettersson U: Arthritis induced in rats with nonimmunogenic adjuvants as models for RA. Immunol Rev 2001, 184:184-202.

6. Trentham DE, Townes AS, Kang AH: Autoimmunity to type II collagen: an experimental model of arthritis. J Exp Med 1977, 146:857-868.

7. Holmdahl R, Malmstrom $\mathrm{V}$, Vuorio E: Autoimmune recognition of cartilage collagens. Ann Med 1993, 25:251-264.

8. Finnegan A, Mikecz K, Tao P, Glant TT: Proteoglycan (aggrecan)-induced arthritis in BALB/c mice is a Th1-type disease regulated by Th2 cytokines. J Immunol 1999, 163:5383-5390.

9. Otto JM, Chandrasekeran R, Vermes C, Mikecz K, Finnegan A, Rickert SE, Enders JT, Glant TT: A genome scan using a novel genetic cross identifies new susceptibility loci and traits in a mouse model of RA. J Immuno/ 2000, 165:5278-5286.

10. Cromartie WJ, Craddock JG, Schwab JH, Anderle SK, Yang CH: Arthritis in rats after systemic injection of streptococcal cell walls. J Exp Med 1977, 146:1585-1602.

11. Joosten LA, Abdollahi-Roodsaz $S$, Heuvelmans-Jacobs $M$, Helsen MM, van den Bersselaar LA, Oppers-Walgreen B, Koenders MI, van den Berg WB: T cell dependence of chronic destructive murine arthritis induced by repeated local activation of TLR driven pathways. Crucial role of both IL-1b and IL-17. Arthritis Rheum 2008, 58:98-108

12. Dumonde DC, Glynn LE: The production of arthritis in rabbits by an immunological reaction to fibrin. Brit J Exp Pathol 1962, 43:373-383.

13. Van den Berg WB, van de Putte LBA, Zwarts WA, Joosten LA: Electrical charge of the antigen determines intraarticular antigen handling and chronicity of arthritis in mice. J Clin Invest 1984, 74:1850-1859.

14. Koenders Ml, Lubberts E, Oppers-Walgreen B, van den Bersselaar L, Helsen MM, Di Padova FE, Boots AM, Gram H, Joosten LA, van den Berg WB: Blocking of IL-17 during reactivation of experimental arthritis prevents joint inflammation and bone erosion by decreasing RANKL and IL-1. Am J Pathol 2005, 167:141-149.

15. Iwakura Y, Tosu M, Yoshida E, Takiguchi M, Sato K, Kitajima I, Nishioka K, Yamamoto K, Takeda T, Hatanaka M: Induction of inflammatory arthropathy resembling rheumatoid arthritis in mice transgenic for HTLV-I. Science 1991, 253:1026-1028.

16. Korganow AS, Ji H, Mangialaio S, Duchatelle V, Pelanda R, Martin T, Degott C, Kikutani H, Rajewsky K, Pasquali JL, Benoist C, Mathis D: From systemic T cell self-reactivity to organ-specific autoimmune disease via immunoglobulins. Immunity 1999, 10:451-461

17. Maccioni $M$, Zeder-Lutz $G$, Huang $H$, Ebel $C$, Gerber $P$, Hergueux J, Marchal P, Duchatelle V, Degott C, van Regenmortel M, Benoist $\mathrm{C}$, Mathis D: Arthritogenic monoclonal antibodies from K/BxN mice. J Exp Med 2002, 195:1071-1077. 
18. Hata $H$, Sakaguchi $N$, Yoshitomi $H$, Iwakura $Y$, Sekikawa $K$, Azuma Y, Kanai C, Moriizumi E, Nomura T, Nakamura T, Sakaguchi S: Distinct contribution of IL-6, TNF-alpha, IL-1 and IL10 to $\mathrm{T}$ cell-mediated spontaneous autoimmune arthritis in mice. J Clin Invest 2004, 114:582-588.

19. Yoshitomi H, Sakaguchi N, Kobayashi K, Brown GD, Tagami T, Sakihama T, Hirota K, Tanaka S, Nomura T, Miki I, Gordon S, Akira S, Nakamura T, Sakaguchi S: A role for fungal (beta)glucans and their receptor Dectin-1 in the induction of autoimmune arthritis in genetically susceptible mice. $J$ Exp Med 2005, 201:949-960

20. Atsumi $T$, Ishihara $K$, Kamimura $D$, Ikushima $H$, Ohtani $T$, Hirota $S$, Kobayashi H, Park SJ, Saeki Y, Kitamura Y, Hirano T: A point mutation of Tyr-759 in IL-6 family cytokine receptor subunit gp130 causes autoimmune arthritis. J Exp Med 2002, 196: 979-990.

21. Sawa $S$, Kamimura $D$, Jin $G H$, Morikawa $H$, Kamon $H$, Nishihara M, Ishihara K, Murakami M, Hirano T: Autoimmune arthritis associated with mutated IL- 6 receptor gp130 is driven by STAT3/IL-7-dependent homeostatic prolifereation of CD4+ T cells. J Exp Med 2006, 203:1459-1470.

22. Niki $Y$, Yamada $H$, Seki S, Kikuchi T, Takaishi H, Toyama $Y$, Fujikawa K, Tada N: Macrophage- and neutrophil-dominant arthritis in human IL-1 alpha transgenic mice. J Clin Invest 2001, 107:1127-1135.

23. Horai R, Saijo S, Tanioka H, Nakae S, Sudo K, Okahara A, lkuse $\mathrm{T}$, Asano M, Iwakura Y: Development of chronic inflammatory arthropathy resembling RA in IL-1ra-deficient mice. J Exp Med 2000, 191:313-320.

24. Nakae S, Saijo S, Horai R, Sudo K, Mori S, Iwakura Y: IL-17 production from activated $T$ cells is required for the spontaneous development of destructive arthritis in mice deficient in IL-1 receptor antagonist. Proc Natl Acad Sci USA 2003, 100:59865990.

25. Horai R, Nakajima A, Habiro K, Kotani M, Nakae S, Matsuki T, Nambu A, Saijo S, Kotaki H, Sudo K, Okahara A, Tanioka H, lkuse T, Ishii N, Schwartzberg PL, Abe R, Iwakura Y: TNF $\alpha$ is crucial for the development of autoimmune arthritis in IL-1 receptor antagonist-deficient mice. J Clin Invest 2004, 114:1603-1611.

26. Terato K, Hasty KA, Reife RA, Cremer MA, Kang AH, Stuart JM: Induction of arthritis with monoclonal antibodies to collagen. $\mathrm{J}$ Immuno/ 1992, 148:2103-2108.

27. Nandakumar KS, Svensson L, Holmdahl R: Collagen type II specific monoclonal antibody-induced arthritis in mice: description of the disease and the influence of age, sex and genes. Am J Pathol 2003, 163:1827-1837.

28. Blom $A B$, van Lent PLEM, van Vuuren $H$, Holthuysen $A E$, Jacobs C, van de Putte LB, van de Winkel JG, van den Berg WB: FcgammaR expression on macrophages is related to severity and chronicity of synovial inflammation and cartilage destruction during experimental immune-complex-mediated arthritis (ICA). Arthritis Res 2000, 2:489-503.

29. Van Lent PLEM, van de Loo FAJ, Holthuysen AEM, van Den Bersselaar LA, Vermeer H, van den Berg WB: Major role for IL-1 but not for TNF in early cartilage damage in immune complex arthritis in mice. J Rheumatol 1995, 22:2250-2258.

30. Nabbe KCAM, Boross P, Holthuysen AEM, Sloëtjes AW, Kolls JK, Verbeek S, van Lent PL, van den Berg WB: Joint inflammation and chondrocyte death become independent of FcyrlII by local overexpression of IFN- $\gamma$ during immune complex mediated-arthritis. Arthritis Rheum 2005, 52:967-974.

31. Monach PA, Benoist C, Mathis D: The role of antibodies in mouse models of rheumatoid arthritis, and relevance to human disease. Adv Immunol 2004, 82:217-248.

32. Ji H, Pettit A, Ohmura K, Ortiz-Lopez A, Duchatelle V, Degott C, Gravallese E, Mathis D, Benoist C: Critical roles for IL-1 and TNF in antibody induced arthritis. J Exp Med 2002, 196:77-85.

33. Schubert D, Maier B, Morawietz L, Krenn V, Kamradt T: Immunization with glucose-6-phosphate isomerise induces $T$ cell dependent peripheral polyarthritis in generally unaltered mice. J Immunol 2004, 172:4503-4509.

34. Iwanami K, Matsumoto I, Tanaka-Watanabe $Y$, Inoue A, Mihara M, Ohsugi $Y$, Goto D, Ito S, Tsutsumi A, Kishimoto T, Sumida T: Crucial role of the IL-6/IL-17 cytokine axis in the induction of arthritis by glucose-6-phosphate isomerase. Arthritis Rheum 2008, 58:754-763.

35. Kuhn KA, Kulik L, Tomooka B, Braschler KJ, Arend WP, Robinson
WH, Holers VM: Antibodies against citrullinated proteins enhance tissue injury in experimental autoimmune arthritis. $J$ Clin Invest 2006, 116:961-973.

36. Hill JA, Bell DA, Brintnell W, Yue D, Wehrli B, Jevnikar AM, Lee DM, Hueber W, Robinson WH, Cairns E: Arthritis induced by posttranslationally modified (citrullinated) fibrinogen in DR4IE transgenic mice. J Exp Med 2008, 205:967-979

37. Uysal $H$, Bockermann $R$, Nandakumar KS, Sehnert B, Bajtner $E$, Engstrom A, Serre G, Burkhardt H, Thunnissen MMGM., Holmdahl R: Structure and pathogenicity of antibodies specific for citrullinated collagen type II in experimental arthritis. J Exp Med 2009, 206:449-462.

38. Kidd BA, Ho PP, Sharpe O, Zhao X, Tomooka BH, Kanter JL, Steinman L, Robinson WH: Epitope spreading to citrullinated antigens in mouse models of autoimmune arthritis and demyelination. Arthritis Res ther 2008, 10:R119.

39. Yuasa T, Kubo S, Yoshino T, Ujike A, Matsumura K, Ono m, Ravetch JV, Takai T: Deletion of Fcgamma receptor IIB renders $\mathrm{H}-2 \mathrm{~b}$ mice susceptible to collagen induced arthritis. J Exp Med 1999, 189:187-194.

40. Tan SC, Mottram PL, van de Velde NC, Powell MS, Power D, Slocombe RF, Wicks IP, Campbell IK, McKenzie SE, Brooks M, Stevenson AW, Hogarth PM: Development of spontaneous multisystem autoimmune disease and hypersensitivity to antibody-induced inflammation in Fcgamma receptor llatransgenic mice. Arthritis Rheum 2005, 52:3220-3229

41. Pietersz GA, Mottram PL, van de Velde NC, Sardjono CT, Esparon S, Ramsland PA, Moloney G, Baell JB, McCarthy TD, Matthews BR, Powell MS, Hogarth PM: Inhibition of destructive autoimmune arthritis in FcgammaRIla transgenic mice by small chemical entities. Immunol Cell Biol 2009, 87:3-12.

42. Boross P, Verbeek JS: The complex role of Fcgamma receptors in the pathology of arthritis. Springer Semin Immunopathol 2006, 28:339-350.

43. Hietala MA, Nandakumar KS, Persson L, Fahlen R, Holmdahl R, Pekna M: Complement activation by both classical and alternative pathways is critical for the effector phase of arthritis. Eur J Immunol 2004, 34:1208-1216.

44. Banda NK, Takahashi K, Wood AK, Holers VM, Arend WP: Pathogenic complement activation in collagen antibody-induced arthritis in mice requires amplification by the alternative pathway. J Immuno/ 2007, 179:4101-4109.

45. Katschke KJ Jr, Helmy KY, Steffek M, Xi H, Yin J, Lee WP, Gribling $\mathrm{P}$, Barck KH, Carano RA, Taylor RE, Rangell L, Diehl L, Hass $\mathrm{PE}$, Wiesmann C, van Lookeren Campagne M: A novel inhibitor of the alternative pathway of complement reverses inflammation and bone destruction in experimental arthritis. J Exp Med 2007, 204:1319-1325.

46. Van den Berg WB: What we learn from arthritis models to benefit arthritis patients. Baillieres Best Pract Res Clin Rheumatol 2000, 14:599-616.

47. Keffer J, Probert L, Cazlaris H, Georgopoulos S, Kaslaris E, Kioussis D, Kollias G: Transgenic mice expressing human tumor necrosis factor: a predictive genetic model of arthritis. $E M B O$ $J$ 1991, 13:4025-4031.

48. Kontoyiannis D, Pasparakis M, Pizarro TT, Cominelli F, Kollias G: Impaired on/off regulation of TNF biosynthesis in mice lacking TNF AU-rich elements: Implications for joint and gutassociated immunopathologies. Immunity 1999, 10:387-398.

49. Kollias G, Douni E, Kassiotis G, Kontoyiannis D: On the role of TNF and receptors in models of multiorgan failure, RA, multiple sclerosis and inflammatory bowel disease. Immunol Rev 1999, 169:175-194.

50. Kassiotis G, Kollias G: Uncoupling the proinflammatory from the immunosuppressive properties of TNF at the p55 TNF receptor level: Implications for pathogenesis and therapy of autoimmune demyelination. J Exp Med 2001, 193:427-434

51. Zwerina J, Redlich K, Polzer K, Joosten L, Kronke G, Distler J, Hess A, Pundt N, Pap T, Hoffmann O, Gasse J, Scheinecker C, Smolen JS, van den Berg WB, Schett G: TNF-induced structural joint damage is mediated by IL-1. Proc Natl Acad Sci USA 2007, 104:11742-11747.

52. Joosten $L A B$, Helsen MMA, van de Loo FAJ, van den Berg WB: Anticytokine treatment of established type II collageninduced arthritis in DBA/1 mice: a comparative study using anti-TNF $\alpha$, anti-IL-1 $\alpha / \beta$ and IL-1ra. Arthritis Rheum 1996, 39: 797-809. 
53. Campbell IK, O'Donnell K, Lawlor KE, Wicks IP: Severe inflammatory arthritis and lymphadenopathy in the absence of TNF. $J$ Clin Invest 2001, 107:1519-1527.

54. Koenders MI, Devesa I, Marijnissen RJ, Abdollahi-Roodsaz S, Boots AM, Walgreen B, di Padova FE, Nicklin MJ, Joosten LA, van den Berg WB: IL-1 drives pathogenic Th17 cells during spontaneous arthritis in IL-1ra deficient mice. Arthritis Rheum 2008, 58:3461-3470.

55. Van den Broek MF, van den Berg WB, van de Putte LBA, Severijnen AJ: Streptococcal cell wall induced arthritis and flare-up reactions in mice induced by homologous and heterologous cell walls. Am J Pathol 1988, 133:139-149.

56. Lubberts E, Schwarzenberger P, Huang W, Schurr JR, Peschon $\mathrm{JJ}$, van den Berg WB, Kolls JK: Requirement of IL-17 receptor signaling in resident synoviocytes for development of full blown destructive arthritis. J Immuno/ 2005, 175:3360-3368.

57. Joosten LA, Netea MG, Kim SH, Yoon DY, Oppers-Walgreen B, Radstake TR, Barrera P, van de Loo FA, Dinarello CA, van den Berg WB: IL-32 a proinflammatory cytokine in RA. Proc Natl Acad Sci USA 2006, 103:3298-3303.

58. De Hooge AS, van de Loo FA, Arntz OJ, van den Berg WB: Involvement of IL-6, apart from its role in immunity, in mediating a chronic response during experimental arthritis. $\mathrm{Am} J$ Pathol 2000, 157:2081-2091

59. Miossec P: IL-17 in fashion, at last: ten years after its description, its cellular source has been identified. Arthritis Rheum 2007, 56:2111-2115.

60. Bettelli E, Oukka M, Kuchroo VK: Th17 cells in the circle of immunity and autoimmunity. Nat Immunol 2007, 8:345-350.

61. Fujimoto M, Serada S, Mihara M, Uchiyama Y, Yoshida H, Koike N, Ohsugi Y, Nishikawa T, Ripley B, Kimura A, Kishimoto T, Naka T: IL-6 blockade suppresses autoimmune arthritis in mice by the inhibition of inflammatory Th17 responses. Arthritis Rheum 2008, 58:3710-3719.

62. Lubberts $E$, van den Bersselaar L, Oppers Walgreen B, Scharzenberger P, Coenen-de Roo CJ, Kolls JK, Joosten LA, van den Berg WB: IL-17 promotes bone erosion in murine collagen induced arthritis through loss of RANKL/OPG balance. J Immunol, 2003, 170:2655-2662.

63. Koenders MI, Lubberts E, van de Loo FAJ, Oppers-Walgreen B, van den Bersselaar L, Helsen MM, Kolls JK, Di Padova FE, Joosten LA, van den Berg WB: Interleukin-17 acts independently of TNF- $\alpha$ under arthritic conditions. J Immunol 2006, 176:6262-6269.

64. Lubberts E, Koenders Ml, Oppers Walgreen B, van den Bersselaar L, Coenen-de Roo CJ, Joosten LA, van den Berg WB: Treatment with a neutralizing anti-murine IL-17 antibody after the onset of collagen arthritis reduces joint inflammation, cartilage destruction and bone erosion. Arthritis Rheum 2004, 50: 650-659

65. Doodes PD, Cao Y, Hamel KM, Wang Y, Farkas B, Iwakura Y, Finnegan A: Development of proteoglycan induced arthritis is independent of IL-17. J Immuno/ 2008, 181:329-337.

66. Luger D, Silver PB, Tang J, Cua D, Chen Z, Iwakura Y, Bowman EP, Sgambellone NM, Chan CC, Caspi RR: Either a Th17 or a Th1 effector response can drive autoimmunity: conditions of disease induction affect dominant effector category. J Exp Med 2008, 205:799-810.

67. Abdollahi-Roodsaz S, Joosten LA, Koenders MI, Devesa I, Roelofs MF, Radstake TR, Heuvelmans-Jacobs M, Akira S, Nicklin MJ, Ribeiro-Dias F, van den Berg WB: Stimulation of TLR2 and TLR4 differentially skews the balance of T cells in a mouse model of arthritis. J Clin Invest 2008, 118:205-216.

68. Abdollahi-Roodsaz S, Joosten LA, Roelofs MF, Radstake TR, Matera G, Popa C, van der Meer JW, Netea MG, van den Berg WB: Inhibition of TLR4 breaks the inflammatory loop in autoimmune destructive arthritis. Arthritis Rheum 2007, 56: 2957-2967.

69. Choe JY, Crain B, Wu SR, Corr M: IL-1 receptor dependence of serum transferred arthritis can be prevented by TLR4 signaling. J Exp Med 2003, 197:537-542.

70. van Lent $P L$, van den Hoek $A E$, van den Bersselaar $L A$, van de Ende M, Dijkstra CD, van Rooijen N, van de Putte LB, van den Berg WB: In vivo role of phagocytic synovial lining cells in onset of experimental arthritis. Am J Pathol 1993, 143:12261237.

71. Lee DM, Kiener HP, Agarwal SK, Brenner MB: Cadherin-11 in synovial lining formation and pathology in arthritis. Science 2007, 315:1006-1010.

72. Nigrovic PA, Binstadt BA, Monach PA, Johnsen A, Gurish M, Iwakura $Y$, Benoist $C$, Mathis D, Lee DM: Mast cells contribute to initiation of autoantibody-mediated arthritis via IL-1. Proc Natl Acad Sci USA 2007, 104:2325-2330.

73. Van den Berg WB: Uncoupling of inflammatory and destructive mechanisms in arthritis. Semin Arthritis Rheum 2001, 30 (Suppl 2):7-16

74. Stanton H, Rogerson FM, East CJ, Golub SB, Lawlor KE, Meeker CT, Little CB, Last K, Farmer PJ, Campbell IK, Fourie AM, Fosang $\mathrm{AJ}$ : ADAMTS5 is the major aggrecanase in mouse cartilage in vivo and in vitro. Nature 2005, 434:648-652.

75. Little CB, Meeker CT, Golub SB, Lawlor KE, Farmer PJ, Smith $\mathrm{SM}$, Fosang AJ: Blocking aggrecanase cleavage in the aggrecan interglobular domain abrogates cartilage erosion and promotes cartilage repair. J Clin Invest 2007, 117:1627-1636.

76. Glasson SS, Askew R, Sheppard B, Carito B, Blanchet T, Ma HL, Flannery CR, Peluso D, Kanki K, Yang Z, Majumdar MK, Morris EA: Deletion of active ADAMTS5 prevents cartilage degradation in a murine model of osteoarthritis. Nature 2005, 434: 644-648.

77. Van Meurs JBJ, van Lent PLEM, Singer II, Bayne EK, van de Loo FA, van den Berg WB: IL-1 ra prevents expression of the metalloproteinase-generated neoepitope VDIPEN in antigeninduced arthritis. Arthritis Rheum 1998, 41:647-656.

78. Nabbe KC, van lent PL, Holthuysen AE, Kolls JK, Verbeek S, van den Berg WB: FcgammaRI upregulation induced by local adenoviral mediated IFNg production aggravates chondrocyte death during immune complex mediated arthritis. Am J Pathol 2003, 163:743-752.

79. van Lent PL, Grevers L, Lubberts E, de Vries TJ, Nabbe KC, Verbeek S, Oppers B, Sloetjes A, Blom AB, van den Berg WB: FcgR mediate cartilage but not bone destruction in murine AIA: uncoupling of cartilage damage from bone erosion and joint inflammation. Arthritis Rheum 2006, 54:3868-3877.

80. Kong YY, Feige U, Sarosi I, Bolon B, Tafuri A, Morony S, Capparelli C, Li J, Elliott R, McCabe S, Wong T, Campagnuolo G, Moran E, Bogoch ER, Van G, Nguyen LT, Ohashi PS, Lacey DL, Fish E, Boyle WJ, Penninger JM: Activated T cells regulate bone loss and joint destruction in adjuvant arthritis through osteoprotegerin ligand. Nature 1999, 402:304-309.

81. Lubberts $E$, Joosten LAB, Chabaud M, van Den Bersselaar L, Oppers B, Coenen-De Roo CJ, Richards CD, Miossec P, van Den Berg WB: IL-4 gene therapy for collagen arthritis suppresses synovial IL-17 and osteoprotegerin ligand and prevents bone erosion. J Clin Invest 2000, 105:1697-1710.

82. Pettit AR, Ji H, von Stechow D, Müller R, Goldring SR, Choi $Y$, Benoist C, Gravallese EM: TRANCE/RANKL knockout mice are protected from bone erosion in a serum transfer model of arthritis. Am J Pathol 2001, 159:1689-1699.

83. Redlich K, Hayer S, Ricci R, David JP, Tohidast-Akrad M, Kollias G, Steiner G, Smolen JS, Wagner EF, Schett G: Osteoclasts are essential for TNF $\alpha$-mediated joint destruction. J Clin Invest 2002, 110:1419-1427.

84. Redlich K, Gortz B, Hayer S, Zwerina J, Doerr N, Kostenuik P, Bergmeister H, Kollias G, Steiner G, Smolen JS, Schett G: Repair of local bone erosions and reversal of systemic bone loss upon therapy with anti-TNF in combination with osteoprotegerin or parathyroid hormone in TNF-mediated arthritis. Am J Pathol 2004, 164:543-555.

85. Zwerina J, Hayer S, Tohidast-Akrad M, Bergmeister H, Redlich K Feige U, Dunstan C, Kollias G, Steiner G, Smolen J, Schett G: Single and combined inhibition of TNF, IL-1 and RANKL pathways in TNF-induced arthritis: effects on synovial inflammation, bone erosion, and cartilage destruction. Arthritis Rheum 2004, 50:277-290.

86. Diarra D, Stolina M, Polzer K, Zwerina J, Ominsky MS, Dwyer D, Korb A, Smolen J, Hoffmann M, Scheinecker C, van der Heide D, Landewe R, Lacey D, Richards WG, Schett G: Dickkopf-1 is a master regulator of joint remodeling. Nat Med 2007, 13:156163.

87. Scharstuhl A, Glansbeek HL, van Beuningen HM, Vitters EL, van der Kraan PM, van den Berg WB: Inhibition of endogenous TGFb during experimental osteoarthritis prevents osteophyte formation and impairs cartilage repair. $J$ Immunol 2002, 169: 507-514. 